Article

\title{
Urban Heritage as Ethos in Resource-Based Small-Scale Property Management
}

\author{
Ingrid Martins Holmberg \\ Department of Conservation, University of Gothenburg, 40530 Gothenburg, Sweden; \\ ingrid.holmberg@conservation.gu.se; Tel.: +46-31-7864716 or +46-708-387981
}

Received: 5 July 2019; Accepted: 18 September 2019; Published: 27 September 2019

\begin{abstract}
This study puts urban heritage in the setting of property owners' small-scale and resource-based management of ordinary old buildings. This phenomenon indicates a need not only to reconceptualize urban heritage in its actual complex web of negotiations over constraints of the regulation (urban planning, including preservation) and economy (the real estate market) but also to pay attention to the emergence of a new ethos. The case concerns a Swedish second-city context and the specific moment in time: When the 1990s recession had disarmed the real estate market. Based upon ethnographic fieldwork, this study used an assemblage perspective to allow for a following of entanglements of material and matter. The study sheds light upon the emergence of a small-scale and resource-based management in the midst of managerially defined cycles of investment. Important for the output was 1) the set-up of a network of skilled craftsmen, antiquarians, and entrepreneurs 'of the right mindset that enabled for the authentic material result but that also helped navigate regulation and financial parties, 2) the "alternative market for reverential maintenance and repair" that guaranteed the appropriate supply of materials, products, and skills that differed from the mainstream construction market. For the means of understanding the ethos involved, the study introduced the notion of "factual life-span of buildings". The overall aim of this article was to contribute to research on heritage urbanism by adding a resource management perspective that focusses on the entanglements of material and matter.
\end{abstract}

Keywords: urban heritage; resource management; entanglements; factual life-span; small property owner

\section{Introduction}

Existing old urban buildings confront heritage practitioners, planners, policymakers, real estate managers, property owners, and citizens alike when it comes to negotiating the relationship between the urban past, present, and future. The different actors involved operate with different rationales, means, material entanglements, and temporal perspectives. While planners mostly conceive of this situation as related to the future (plans), and official heritage officers conceive of it as a question of the representation of history (as heritage), this article would situate the very general question of how new notions of urban heritage emerges and materializes, in the specific context of small-scale urban property owners in the 1990s Sweden. From the observations in this particular context, the article discusses what urban heritage is about, and in what direction conceptual development is needed to encircle its relationship to larger challenges about sustainability. The main argument is that any up-to-day conceptualization of urban heritage needs to acknowledge urban heritage as a particular outcome. It is not about the particularities of the object of concern (old and with artistic qualities or alike), it is not about which are the specific actors and initiatives involved (the authorization given), and it is not about the discourses involved. It is not even about the future as such. To encircle its 
relevance, heritage research—methods, perspectives, empirical material, and interpretations-must aim beyond structuralist understandings.

The article suggested that urban heritage is about oeconomia, meaning housekeeping, husbandry, and economy in the sense of using resources wisely, for gain beyond the individual, and with long-term perspectives. It includes activities of saving, safeguarding, mending, and care-taking, and it is an activity in opposition to exploitation. The focus enabled is that of urban heritage as a particular outcome, instead of as a particular kind of objects, or objects defined by particular actors, etc. The focus on outcome enables evaluation. Do the activities of concern promote sustainability? Which kind of sustainability? In this context, sustainability is encircled as resource-saving practices. Support of the argument of urban heritage as a particular outcome is drawn from the recent conceptualization of urban heritage in terms of "heritage urbanism" [1], see below. Accordingly, the overall aim of this article was to contribute to research on heritage urbanism by adding empirical observations from the context of small-scale property management. The perspective employed allows a focus on the entanglements of material and matter. The main contribution is the identification of property owners' explicit resource-based ethos and contextualization of this ethos. We have observed the key role played by first-informal networks consisting of craftsmen, heritage specialists, planning officers, and entrepreneurs, and second an "alternative market for repair of old buildings". This alternative market consists of the exchange of old reused parts and details from old buildings (instead of modern additions) and by the exchange of skills, know-how, and skilled craft (instead of cheap quick-fix).

In employing a perspective of (human and material) entanglement, buildings are a kind of assemblage "always being assembled and reassembled in changing configurations" [2,3]. However, buildings also introduce a unique temporal dimension. The notion of a "factual life-span of buildings" refers to an essential phenomenal socio-material capacity of buildings to endure over very long time-period; buildings embody the capacity of a much longer life-cycle than humans. This very capacity may bring a set of particular human practices, including to observe, to act upon, and to develop. Practices, such as these, may, therefore, be deviant from the expected management schemes to meet the inevitable write-off through recurrent cycles of substantial reinvestments. In every-day language, the outcome is called modernization or development. The "factual life-span of buildings" is the fact that certain conditions can bring a correction to the rational schemes and push an ordinary old building in the direction of "heritage", i.e., to become "old-and-nice" and worth "saving". In the following, previous research and understanding of the attraction of old urban buildings were delineated. Then, the core concepts that have guided the research were introduced.

Much previous research and discussion about the role of old buildings in urban contexts is concerned with the causes and underlying reasons for the attraction of old buildings and emphasizes changes in power relation in a structural framework. Emphasis has, for example, been put on the quest for the renovation of old buildings in the urban core as an output of particular and class-based heritage conceptions and a forerunner to urban gentrification [4]. These would then be a merely aesthetic outcome of the constitution of the new middle class that has originated from the restructuring of the labor market. This line of understanding points out the post-industrial liberal economic arena forging art and economy in new mixes (second-hand stores, antiquities shops, and art galleries) and producing (the need for) new kinds of spaces, such as exhibition halls and loft apartments [5,6]. While some researchers have considered interest in old houses as driven by an individualistic and self-contained postmodern human subjectivity, shackled in self-presentation and self-fulfillment, others have instead pointed at the cumbersome desire for keeping one's life-worlds, and that this is connected to a social criticism towards brutal modernist urban planning $[7,8]$. There is also research delineating the genealogies of particular geographical imaginations, foregoing and directing the discursive turn into an extended urban heritage and new kinds of urban preservation $[9,10]$. A major line of research has developed around issues of different kinds of relations between preservations regulation (safeguarding and listing), and spatial planning with the main aim to balance public and private interests [11,12]. Here, "urban heritage" is the outcome of selection and regulation under the header of an authorized 
heritage discourse that while differing between nations and over time, still focus on setting apart particular jewels. As shown, the major lines of understandings are accordingly concerned with structures: The (reasons to and effects of) closures of rent-gaps at one end of the scale, and the (various and changing reasons to and effects of) heritage regulation on the other end. Emerging research contextualizes urban heritage as to varying degrees related to and incorporated in a spectrum of implicit or explicit urbanisms [13].

A critical reflection is that many of these research inputs seem to depart from certain pre-conceptions that include un-articulated modernist views of the world. Any other practice than the regular replacing of old urban buildings with new ones (the rational exploitation of rent gaps) is deviant to the norm. From such perspectives, heritage as a phenomenon, including its institutions and regulations, becomes a target of critique [14], but more importantly, it brings understandings of urban transformations where care-taking, ethos, emotions, and alike, by default are made into abnormalities.

The research presented in this article suggested that a more comprehensive understanding of the very appearance and robust sustainability of old buildings in urban contexts could be reached by using the perspective of entanglement. This enables for a more modest understanding, but one that allows a focus on the actual connections that the phenomenon of concern is an integral part of. Central for the research of this paper were a series of concepts that encircle a contextual understanding: "heritage urbanism", "care-taking", and "alternative markets".

For this paper, I departed from the concept of 'heritage urbanism' as developed by Bojanić Obad and Šćitaroci 2019 [1]. While rooted in planning, heritage urbanism aims at finding a general methodology to enhance heritage. Heritage is here viewed not as isolated objects defined by particular actors, but rather related to the immediate and wider environment and how this becomes engaged in particular aims to create a more sustainable future. As a concept, "heritage urbanism" encircles how different approaches in different ways relate to sustainable ways to plan for the future [1]. Emerging research in other fields supports this understanding and emphasizes the importance of a more comprehensive understanding of practices of care-taking, particularly in terms of repair [15]. This paper understood repair as many kinds of engagements that take place in "between breakdown and restoration of the practical equilibrium" [15]. Research on repair practices related to buildings is still emerging, with some notable exceptions [3]. The separate research field, called building conservation/preservation, based upon best-practice, is considered as an example itself of the phenomenon and was thus left aside in this article. On the larger urban scale, practices of repair include a wide range of professionals, such as plumbers, painters, carpenters, dustmen, glaziers, etc. This is what Nigel Thrift's notion of "urban glue" is about: The ways in which an entire city can hold together by a whole host of activities that are constantly ongoing and that are carried out by amateurs as well as a wide range of professionals. All these activities make the urban fabric and constructions sustainable. They counteract deterioration, wear, and entropy. This notion illuminates the many ways in which the city's material fabric remains intact through practices of maintenance and repair $[16,17]$, and do relate to the conceptualization of heritage as an outcome discussed above.

A central concern of this paper was to address the connection of practices of repair to markets. Markets evolve at the intersection of politics, economy, and ecology and require a specific organization [18-20], meaning a context and network where particular items-material and skills-are exchanged. It is necessary to relate property managers care-taking activities to the construction market; but for this research, the notion of "market" needs elaboration. The concept of "alternative markets" enables for a distinction. Core components in an alternative market are plurality as well as relationships: A "huge variety of economic transactions, labor practices, and economic organizations that contribute to social well-being worldwide", also involving aspects, such as non-markets and unpaid labor [21]. The market of concern in this paper-the trade of skills, knowledge, as well as items, to enable repair activities of old buildings has a distinctly marginal position in relation to the regular construction market (that aims at modernization or regular renewal), and in this paper was conceptualized "alternative". 


\section{Materials and Methods}

This article was based on qualitative studies. The main empirical material concerned stakeholders as well as minor actors, such as property owners active in the reinvestment in and renovation of old urban buildings during the 1990s in the geographic area of central Gothenburg, in south-western Sweden. The analysis was informed by several previous studies in this area and this field of knowledge $[9,22]$. The methodological perspective was drawn from the school of hermeneutics, and the empirical strategy was motivated by the aim to complement previous studies on urban heritage and heritage urbanism. The material was gathered in ethnographic fieldwork and included extensive interviews, as well as document analysis, in combination with on-site observations. The time-period for the fieldwork was 2016-2017, and the interviews were performed on-site at properties and in the street, as well as in offices.

\section{Results and Discussion}

In the late 1980s, most central quarters of Gothenburg were either developed into commercial large-scale use, like Nordstan-the biggest shopping mall of northern Europe, or were run-down and marked by the city planning department as ripe for redevelopment. The run-down properties were located at the fringe of the urban core. An economic recession in the early 1990s added on to this and brought a complete status quo on the real estate market. At this time, a mid-career lawyer, for the sake of the article named $\mathrm{Mr}$. $\mathrm{H}$, realized the amazing opportunities for creative navigation between official planning regulation and cycles of the real estate market: Although it was business, he recalled it as a deliberate support of another kind of city planning than he had seen it the preceding decade. In the position as property owner and developer, he was able to combine his professional competence with his personal interest in old buildings: "because they are beautiful". To understand the navigation of $\mathrm{Mr}$. $\mathrm{H}$, the article contextualized his rationales both in relation to the general logic of property management and in relation to networks of an alternative market.

Even if the scale of Mr. H's economic activities were moderate at this moment in time, it marks the emergence of a kind of resource-based management of ordinary old urban buildings. In the local context, the decade before had brought restoration and safeguarding of urban buildings through the means of listing and state incentives, in short, a process driven by the planning authorities against the property owners' will to reinvest and develop. A key example is the case of the preservation of the old buildings in the area of Haga, a run-down former working-class district. In the early 1960s, an exploitation company, run by the city and half-owned by corporate business, had managed the purchase of huge urban areas consisting of ordinary old buildings. The buildings were marked as ripe for clearance and redeveloped. When activities reached the area of Haga, local protests marked a reaction against large scale redevelopment. The local reactions, driven by well-organized and skillful locals, architects, and academics, were soon supported by national mass media. Most striking in the revaluation was the complete turnaround by politicians and planning authorities: From large-scale demolition to recognition of local values and heritage qualities of Haga. The ten-year struggle by activists ended in the preservation of the area of Haga and the designation as the heritage of more than sixty ordinary old urban buildings, owned by private property owners as well as the city itself $[9,23,24]$. Haga became recognized as heritage and preserved through the means of official designation. Although the primary reason to counteract the demolition of Haga was resource-based (the inhabitants wished to stay put), the transformation of Haga into heritage was based upon public incentives and initiatives, such as listing. The identity of Haga became part of an authorized heritage discourse (AHD). When, ten years later, small-scale property owners took the lead in preservation, the roles were different.

At the time for the economic recession and the status quo of the real estate market with zero investments, Mr. H came into companionship with the owner of a small fashion boutique. The owner needed a better location for his shop. Both realizing the best location was in central underdeveloped properties, they decided to put their efforts into buying a suiting central rundown property. The vision was to put together the shop's boutique concept (a personalized small batch of selected commodities) 
with the actual qualities of the building-its patina and small-scale structure-and this was the re-start of their careers within real estate, leading to a prominent position as real estate managers of old buildings for a few decades.

This idea was later developed in different ways, and in varying shapes of partnership, always prioritizing the match of the character of the actual premises in question, to the renter and/or business. The market niche that they envisioned was that of combining a particular customer/renter with the particular premises: The renter was a small-scale not-yet established business, shop, or office, with no economic capital, but needs, that could be easily matched in old buildings in the central quarters. Here the idea of small-scale interventions emerged, perfectly suiting the renter who needed a low rent. "In the beginning, I fell in the trap of wanting to make everything too nice. After a while, I learned that it doesn't have to be perfect. It was of most importance that the rent for premises could be kept at a low level. Because the initial investment was low, it was easy for us to keep the rents down if we did not make too much renovation."

Mr. H built was active on the real estate market of Gothenburg for several decades. From early on, he established an informal network that consisted of business partners, planners, heritage experts but also entrepreneurs and craftsmen. He considered the last category as crucial. From the very beginning, he needed craftsmen with the right attitude and compatible skills. He mentioned the flooring contractor, Glenn, who was able to provide traditional linseed raisin-based lacquers for the floors: "when you wish to let a premise, you have to take care of the floors. If there are stains on the walls and the ceiling, it's all compensated by a renovated and lacquered floor." In fact, the floors were the main focus, and most efforts were put into keeping them nice-and-authentic. The use of plastic-based lacquers was a big no-no. Other core skills were the electrician and the plumber. They were essential for the result: Their competence and interest in the particular and special solutions of minimal intervention could enable a certain degree of modernization but still not too much. The solutions of standard modernization were not applicable, so creativity became a keyword. Mr. $\mathrm{H}$ was himself engaged in the particular and very specific solutions and didn't leave even the applications of new cables, ducts, pipes, etc. to the craftsmen until they had shown their competence. Every intervention should be in tune with the buildings' atmosphere.

The network gradually extended to a lot of other people with similar ideas. Realizing that property owners played a key role in urban planning, the city planning department and board, at that time, took an interest in the process, paying a visit and discussed. As the buildings stock grew, and when the building permit was needed, Mr. H consulted a heritage specialist who prepared the documentation of each building and suggested strategies for allowance. Often, also the city museum was engaged. This was a successful way to get the allowance needed, but most of all, it turned the role around: In this case, the property owner came up with the preservation initiative instead of the heritage and planning authorities.

From early on, Mr. H searched for people that shared his interest in the reuse of old building material. One of them was Lars, an archeologist by training and a university employee working as a teacher in building preservation, but most of all, an enthusiastic track-finder of momentarily redundant old building material. On the agenda were activities like container-diving, visits at demolition sites, as well as negotiations with owners of demolition objects. Suitable items, details, or material and stuff were found everywhere and put in place in the property that, for the moment, was under renovation. The findings were random but always of uttermost importance. Since renovation business is about timing (the right thing in the right time), Mr. H soon realized the need to support the supply market for reused building parts himself. The scouting for appropriate items was directed in particular directions, one of which was Hus-till-hus, established in the late 1980s. Items with the right look, the right feel, or even the right style could now be found, purchased, and inserted in a regular manner. Along with the development of Mr. H's property business to include also old industrial buildings in the urban periphery, space was made for companies that indirectly could support the supply, like a wallpaper company that specialized in vintage patterns printed with old school pigments. 
The alternative market for repair and maintenance that gradually emerged in the urban region during the 1990s could offer not only reused building material, like old windows, door-knobs, and tiles that came from demolition projects or were handed in by laymen but also shining new items in period styles. This market both fed into the property owner's need and was also itself a product of his investments. A salient market item is the competence and skills that are offered, both as commodities and as services for the customer. It is about craft skills but also networks for supply. Where can one find a door that fits and who can set it in place, so it works properly? This market emerged during the period of resource-based management. The interviews indicated the real estate owner's strong reliance on the market [22].

\section{Conclusions}

The article argued that the phenomenon of property owners' small-scale and resource-based management of ordinary old urban buildings indicates a need to reconceptualize urban heritage as a particular outcome. The article suggested that urban heritage is about oeconomia, in the sense of using resources wisely, for gains beyond the individual, and with long-term perspectives, including activities of saving, safeguarding, mending, and care-taking, here encircled as resource-saving practices. This moves urban heritage beyond both idealist and structuralist understandings, focusing on particular kinds of objects or objects defined by particular actors, etc. The perspective employed allows a focus on the entanglements of material and matter.

The article presented the emergence of a new kind of management ethos of urban ordinary buildings among real estate owners: Resource-based management. Preservation in this field, outside of regulation (listing, preservation) appears as based upon the notion of resources-management "reverential maintenance and repair of the existing fabric of old buildings", and set-up in contrast to ordinary managerially-defined cycles of investment. With property owners taking the lead, the local planning authorities and local official heritage institutions followed in the tracks. In this situation, the character of real estate management appeared as less related to the mere rational exploitation of rent-gaps, or tactic navigation between different modes of governance and clutters of regulation. Instead, we can discern how a certain mindset among property owners, an ethos, made up the framework for actions. This ethos was about resource-based reverential maintenance of old buildings as well as about an acknowledgment of existing qualities of 19th-century urban space. This idealist ethos, however, cannot be distinguished by its eloquent discourse alone but is entangled in a wide range of different practices of economy, some of which follow the calculated time-schemes of real estate management, some of which play out completely different temporal scales. In this case, we discerned a particular material outcome: The reuse of old buildings that, while often undergoing renovation, restoration, or rebuilding, this has been performed with attendance to minimal waste of recourses in combination with minimal interventions and careful choice of reversible materials.

The main contribution is the identification of property owners' explicit resource-based ethos and contextualization of this ethos. For the means of understanding the ethos involved, the study introduced the notion of "factual life-span of buildings". We observed the key role played by first-informal networks consisting of craftsmen, heritage specialists, planning officers, and entrepreneurs, and second an "alternative market for repair of old buildings". This alternative market consists of the exchange of old reused parts and details from old buildings (instead of modern additions) and by the exchange of skills, know-how, and skilled craft (instead of cheap quick-fix).

The alternative market for repair and maintenance was, of course, entangled in a broad spectrum of other kinds of concerns and economies, each organized in a particular way [22]. So, while conceiving of it as an alternative market, it shall not be conflated with the fact that repair and maintenance of old buildings are not one singular activity, or set of activities, with one coherent set of actors. The common terms that indicate distinctions between different kinds of practical interventions aiming at maintenance, such as restoration, replication, repristination, conservation, or anastylosis from the context of conservation of heritage buildings, however, appear as complexly intertwined in practice [25]. 
Graham and Thrift state that: "Repair and maintenance do not have to mean exact restoration. Think only of the bodged job, which still allows something to continue functioning but probably at a lower level; the upgrade, which allows something to take on new features which keep it contemporary; the cannibalization and recycling of materials, which allows at least one recombined object to carry on, formed from the bones of its fellows; or the complete rebuild, which allows something to continue in near pristine condition" [15]. What seems to be a clear terminology in one context is a complex practice loaded with compromises in real situations. Following Graham and Thrift, above, the old urban buildings of concern here were not neutral backdrops for a set of easily encircled sociocultural practices. In these other networks, the old buildings did stand out as individuals, sometimes even with persona qualities. They were entangled in human and non-human networks where they became engaged in other ways than they would have been in the context of mainstream modernization projects.

Funding: This research was funded by two research projects: The Swedish Research Council: "Re:heritage. Circulation and marketization of things with history" (\#2013-1923). PI: PhD. Anna Bohlin, Dept. of Global studies, University of Gothenburg; The Swedish Research Council "Maintenance Matters: Exploring common contexts of heritage (e)valuation" (\#2016-02528). PI: Ingrid Martins Holmberg, Dept. of Conservation, University of Gothenburg.

Conflicts of Interest: The authors declare no conflict of interest.

\section{References}

1. Bojanić Obad, M.; Šćitaroci, B. Heritage Urbanism. Sustainability 2019, 11, 2669. [CrossRef]

2. Sheller, M.; Urry, J. The new mobilities paradigm. Environ. Plan. A 2006, 38, 207-226. [CrossRef]

3. Edensor, T. Entangled agencies, material networks and repair in a building assemblage: The mutable stone of St Ann's Church, Manchester. Trans. Inst. Br. Geogr. 2011, 36, 238-252. [CrossRef]

4. Jager, M. Class definition and the esthetics om gentrification: Victoriana in Melbourne. In Gentrification of the City; Smith, N., Williams, P., Eds.; Allen \& Unwin: Winchester, UK, 1986.

5. Zukin, S. The social production of urban cultural heritage: Identity and ecosystem on an Amsterdam shopping street. City Cult. Soc. 2012, 3, 281-291. [CrossRef]

6. Zukin, S. Gentrification: Culture and Capital in the Urban Core. Annu. Rev. Sociol. 1987, 131, $129-147$. [CrossRef]

7. Caulfield, J. 'Gentrification' and desire. Can. Rev. Sociol. 1989, 26, 617-632. [CrossRef]

8. Schönbeck, B. Stad i förvandling: Uppbyggnadsepoker och Rivningar i Svenska Städer från Industrialismens Början till Idag; Byggforskningsrådet: Stockholm, Sweden, 1994.

9. Holmberg, I.M. På Stadens Yta: Om Historiseringen av Haga. Ph.D. Thesis, University of Gothenburg, Göteborg, Sweden, 2006.

10. Holmberg, I.M. Med bebyggelsehistoria som medel: Om relationer mellan kunskapsbildning och uppvärdering av äldre stadsbebyggelse. Bebyggelsehistorisk Tidskrift 2011, 60, 78-93.

11. Tunbridge, J.E.; Ashworth, G.J. Dissonant Heritage: The Management of the Past as a Resource in Conflict; Wiley: Chicester, UK, 1996.

12. Pendlebury, J.; Scott, M.; Veldpaus, L.; van der Toorn Vrijthoff, W.; Redmond, D. After the Crash: The conservation-planning assemblage in an era of austerity. Eur. Plan. Stud. 2019. [CrossRef]

13. Olsson, K.; Nilsson, D.; Haas, T. Urbanismer: Dagens Stadsbyggande i Retorik och Praktik; Nordic Academic Press: Lund, Sweden, 2016.

14. Hewison, R. The Heritage Industry: Britain in a Climate of Decline; Methuen: London, UK, 1987.

15. Graham, S.; Thrift, N. Out of Order: Understanding Repair and Maintenance. Theory Cult. Soc. 2007, 24, 1-25. [CrossRef]

16. Thrift, N. But malice aforethought: Cities and the natural history of hatred. Trans. Inst. Br. Geogr. 2005, 30, 133-150. [CrossRef]

17. Olshammar, G. Creating the City: Identity, Memory and Participation. In Proceedings of the Conference Creating the City, Malmo, Sweden, 9-10 February 2017; Malmo University: Malmo, Sweden, 2017; pp. $20-45$.

18. Bialski, P.; Derwanz, H.; Otto, B.; Vollmer, H. 'Saving' the City: Collective Low-Budget Organising and Urban Practice. Ephemera 2015, 15, 1-19. 
19. Perey, R.; Benn, S. Organising for Ecological Repair: Reconstructing Land Management Practice. Organ. Environ. 2015, 28, 458-477. [CrossRef]

20. Wiens, K. The repair revolution. In Things Come Apart: A Teardown Manual for Modern Living; McLellan, T., Ed.; Thames and Hudson: London, UK, 2013.

21. Gibson-Graham, J. Diverse economies: Performative practices for 'other worlds'. Prog. Hum. Geogr. 2008, 32, 613-632. [CrossRef]

22. Holmberg, I.M.; Palmsköld, A.; Barnholdt, R. Återbruk och Byggnadsvård. Cirkulering av delar och Detaljer Från äldre Byggnader; Makadam Publishers: Göteborg, Sweden, 2017.

23. Holmberg, I.M. Arbetarens nya kläder: Om industrisamhällesidentitet i den postindustriella stadens imaginära landskap. In Storstadens omvandlingar: Postindustrialism, Globalisering och Migration: Göteborg och Malmö; Sernhede, O., Johansson, T., Eds.; Daidalos: Göteborg, Sweden, 2006.

24. Thörn, H. Stad i rörelse: Stadsomvandlingen och Striderna om Haga och Christiania; Atlas Akademi: Stockholm, Sweden, 2013.

25. Bold, J.; Larkham, P.; Pickard, R. Authentic Reconstruction: Authenticity, Architecture and the Built Heritage; Bloomsbury Publishing Plc: London, UK, 2017.

(C) 2019 by the author. Licensee MDPI, Basel, Switzerland. This article is an open access article distributed under the terms and conditions of the Creative Commons Attribution (CC BY) license (http://creativecommons.org/licenses/by/4.0/). 